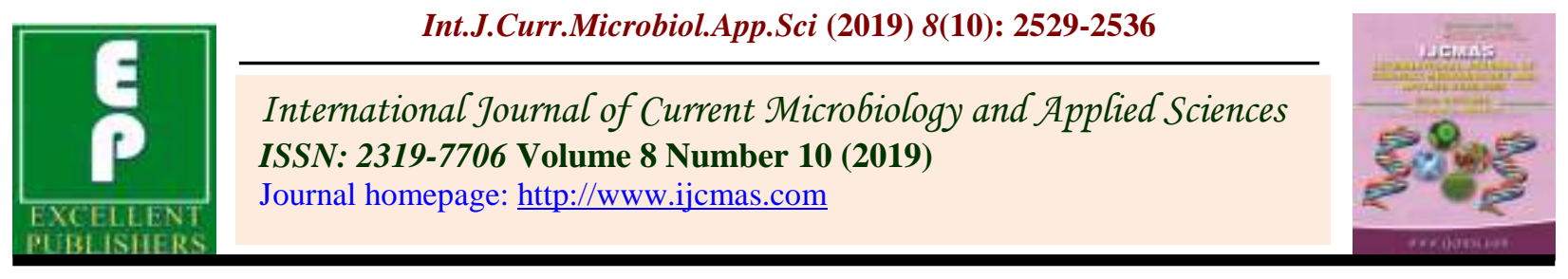

Original Research Article

https://doi.org/10.20546/ijcmas.2019.810.293

\title{
A Comparative Analysis on Profile and Problems of Soliga and Kuruba Tribal Youths
}

\author{
T.P. Bharath Kumar*, M.S. Nataraju and M.T. Lakshminarayan \\ KrishiVigyan Kendra, Chikkamagaluru, University of Agricultural and Horticultural \\ Sciences, Shivamoogga, Karnataka, India \\ *Corresponding author:
}

Keywords

Profile, Tribal youths, Problems, Suggestions, Livelihood status

Article Info

Accepted:

18 September 2019

Available Online:

10 October 2019

\section{A B S T R A C T}

The present study was conducted in Heggadadevanakote and Hunsurtaluks in Mysore district and Gundlupet and Kollegaltaluks in Chamarajanagar district in Karnataka during 2017-2018 to know the profile and problems of Soliga and Kruba tribal youths. Eighty Soliga tribal youth from two taluks of Chamarajanagar district and 80 Kuruba tribal youth from two taluks of Mysore district formed the sample of the study. Thus the total sample constitutes to 160 tribal youth. The collected data was scored, tabulated and analyzed using frequency, percentage and ranks. The results revealed there is difference in the personal, socio-economic, psychological and communication characteristics between Soliga and Kurubatribal youths. Inadequate land for cultivation, uncertainty of rainfall inadequate fodder for cattle and inadequate irrigation facilities for farming and to maintain live stock were the major problems faced by Soliga and Kuruba tribal youths. The important suggestions of the tribal youths for improving their livelihood status are: Need of 'Record of Right Tenancy and Crops (RTC)' in the name of tribal youth, establishment of small scale enterprises, organizing the training programmes at village level on improved farm technologies and increase the support price for agriculture produce.

\section{Introduction}

India constitutes about 8.61 per cent $(8.97$ million) of tribal population compared to total population of the country (104.28 million) (2011 Census) and covers about 15 per cent of the country's area. Karnataka is the home to $42,48,987$ tribal people, registering a decennial growth rate of 22.66 per cent. Although the tribals people represent only 6.95 per cent of the population of the state, there are as many as 50 different tribes notified by the Government of India, living in Karnataka, of which 14 tribes including two primitive ones, are primarily natives of this state. Jenu Kuruba, Betta Kuruba/Kadu Kuruba, Yarava and Soliga are some of the ethnic groups found in southern districts (Mysore and Chamarajanagara districts) of Karnataka. These two districts are located in southern part of the Karnataka and National Reserve Forests of Nagarahole, Bandipura 
and B.R. Hills forests are also located in these districts. Among the above tribes, Jenu Kuruba is the primitive tribe and Soliga and Jenu Kuruba tribes are the major groups, whereas KaduKuruba and Yarava are smaller tribal groups. In terms of population, Soliga tribe is a major tribe in Chamarajanagara district and JenuKuruba is the major tribe in Mysore district. In this backdrop, the present study was undertaken with the specific objectives:

To know the profile of Soliga and Kuruba tribal youths and also to document the problems and suggestions of Soliga and Kuruba tribal youths for improving their livelihood status.

\section{Materials and Methods}

The present investigation was carried out in Chamarajanagar and Mysore districts of Karnataka state during 2017-18. Chamarajanagar and Mysore districts were purposively selected for the study since they are having highest population of Soliga and Kuruba tribes. Heggada DevanaKote and Hunsurtaluks in Mysore district and Gundlupet and Kollegaltaluks in Chamarajanagar district were also purposively selected for the study since these taluks in the sampled two districts were having highest number of tribal families and higher number of hadies.

From each of the sampled four taluks, two forest fringe villages were randomly selected for the study. In each village, 20 tribal youth were again selected randomly for the study. Eighty Soliga tribal youth from two taluks of Chamarajanagar district and 80 Kuruba tribal youth from two taluks of Mysore district formed the sample of the study. Thus the total sample constitutes to 160 tribal youths. The collected data was scored, tabulated and analyzed using frequency, percentage and ranks.

\section{Results and Discussion}

Personal, socio-economic, psychological and communication characteristics of tribal youths

The personal, socio-economic, psychological and communication characteristics of tribal youths are presented in Table 1.

\section{Education}

The results in Table 1 reveal that 38.75 per cent of Soliga youth are having high level of education, whereas 31.25 and 30.00 per cent were having medium and low level of education respectively. Majority $(60.00 \%)$ of Kuruba youth had low level of education followed by medium $(30.00 \%)$ and high $(10.00 \%)$ level of education.

\section{Marital status}

More than the three-fourth of Soligayouth were unmarried $(76.25 \%)$ and the remaining 23.75 per cent of them were married (Table 1). Similarly, more than three-fourth of Kurubayouth were unmarried $(76.25 \%)$ and the rest of them were married $(23.75 \%)$.

\section{Family size}

A perusal of Table 1 reveals that nearly half of the Soligayouth had small family (48.75 $\%)$ followed by medium (45.00 \%) and large family $(6.25 \%)$. As high as 47.50 per cent of Kurubayouth had small family, whereas 45.00 and 7.50 per cent of them had medium and large family, respectively.

\section{Land holdings}

More than half of the Soligayouth interviewed were marginal farmers $(57.50 \%)$ and 28.75 per cent of Soligayouth interviewed were small farmers and the remaining Soliga 
youths interviewed were big farmers $(11.00 \%)$. A greater proportion of Kurubayouth interviewed were marginal farmers $(58.75 \%)$ followed by 30.00 per cent small farmers and 11.25 per cent big farmers.

\section{Annual income}

The data in the Table 1 also shows that 45.00 per cent of Soligayouth were belonging to medium income group followed by 32.50 per cent belonging to low income group and the rest 22.50 per cent belonging to high income group.

As high as 46.25 per cent of Kurubayouth belonging to medium income group followed by 32.50 per cent belonging to low income group and the remaining 21.25 per cent of them were belonging to high income group.

\section{Mass media use}

It is found from Table 1 that 42.50 per cent of Soligayouth belong to medium category of mass media use followed by high $(31.25 \%)$ and low $(26.25 \%)$ category of mass media use (Table 1). Forty per cent of Kurubayouth fall under medium category of mass media use, where as 32.50 and 27.50 per cent of them belonged to high and low category of mass media use, respectively.

\section{Extension contact}

It is observed in Table 1 that 42.50 per cent of Soligayouth belong to low category of extension contact followed by medium $(31.25 \%)$ and high $(26.25 \%)$ category of extension contact. Whereas, 41.25 per cent of Kurubayouth were belonging to low category of extension contact followed by medium $(33.75 \%)$ and high $(25.00 \%)$ category of extension contact.

\section{Extension participation}

A perusal of Table 1 revealed that more than two-third of Soligayouth $(67.50 \%)$ fall under low category of extension participation followed by high $(20.00 \%)$ and medium $(12.50 \%)$ category of extension participation. Similar result were observed with respect to Kuruba youth, wherein 68.75 per cent belong to low category of extension participation followed by high $(18.75 \%)$ and medium $(12.50 \%)$ category of extension participation..

\section{Cosmopoliteness}

It is seen from Table 1 that a majority of Soliga youth belong to high category of cosmopoliteness $(53.75 \%)$ followed by low $(36.25 \%)$ and medium $(10.00 \%)$ category of cosmopoliteness. More than half of Kuruba youth belong to high category of cosmopoliteness $(56.25 \%)$ followed by low $(35.00 \%)$ and medium $(08.75 \%)$ category of cosmopoliteness.

\section{Achievement motivation}

Table 1 revealed that more than half of Soligayouth $(58.75 \%)$ belong to high category of achievement motivation followed by low $(32.50 \%)$ and medium $(8.75 \%)$ category of achievement motivation. As high as 60.00 per cent of Kuruba youth were belonging to high category of achievement motivation followed by low $(30.00 \%)$ and medium $(10.00 \%)$ category of achievement motivation. More or less similar findings were observed by Rokonuzzaman (2013) and Yashodhara (2015).

It can be inferred from the above results that there is difference in the personal, socioeconomic, psychological and communication characteristics between of Soliga and Kurubatribal youths. 
Table.1 Personal, socio-economic, psychological and communication characteristics of tribal youths

\begin{tabular}{|c|c|c|c|c|c|c|}
\hline \multirow{3}{*}{$\begin{array}{l}\text { Sl. } \\
\text { No. }\end{array}$} & \multirow[t]{3}{*}{ Characteristics } & \multirow[t]{3}{*}{ Category } & \multicolumn{4}{|c|}{ Tribal youths } \\
\hline & & & \multicolumn{2}{|c|}{$\begin{array}{c}\text { Soliga } \\
\left(\mathbf{n}_{1}=\mathbf{8 0}\right)\end{array}$} & \multicolumn{2}{|c|}{$\begin{array}{c}\text { Kuruba } \\
\left(\mathbf{n}_{2}=80\right)\end{array}$} \\
\hline & & & No. & $\%$ & No. & $\%$ \\
\hline \multirow[t]{3}{*}{1} & \multirow[t]{3}{*}{ Education } & Low & 24 & 30.00 & 48 & 60.00 \\
\hline & & Medium & 25 & 31.25 & 24 & 30.00 \\
\hline & & High & 31 & 38.75 & 08 & 10.00 \\
\hline \multirow[t]{2}{*}{2} & \multirow[t]{2}{*}{ Marital status } & Married & 19 & 23.75 & 19 & 23.75 \\
\hline & & Unmarried & 61 & 76.25 & 61 & 76.25 \\
\hline \multirow[t]{3}{*}{3} & \multirow[t]{3}{*}{ Family size } & Small & 39 & 48.75 & 38 & 47.50 \\
\hline & & Medium & 36 & 45.00 & 36 & 45.00 \\
\hline & & Large & 05 & 06.25 & 06 & 07.50 \\
\hline \multirow[t]{3}{*}{4} & \multirow[t]{3}{*}{ Land holding } & Marginal farmers & 46 & 57.50 & 47 & 58.75 \\
\hline & & Small farmers & 23 & 28.75 & 24 & 30.00 \\
\hline & & Big farmers & 11 & 13.75 & 09 & 11.25 \\
\hline \multirow[t]{3}{*}{5} & \multirow[t]{3}{*}{ Annual income } & Low & 26 & 32.50 & 26 & 32.50 \\
\hline & & Medium & 36 & 45.00 & 37 & 46.25 \\
\hline & & High & 18 & 22.50 & 17 & 21.25 \\
\hline \multirow[t]{3}{*}{6} & \multirow[t]{3}{*}{ Mass media use } & Low & 21 & 26.25 & 22 & 27.50 \\
\hline & & Medium & 34 & 42.50 & 32 & 40.00 \\
\hline & & High & 25 & 31.25 & 26 & 32.50 \\
\hline \multirow[t]{3}{*}{7} & \multirow[t]{3}{*}{ Extension contact } & Low & 34 & 42.50 & 33 & 41.25 \\
\hline & & Medium & 25 & 31.25 & 27 & 33.75 \\
\hline & & High & 21 & 26.25 & 20 & 25.00 \\
\hline \multirow[t]{3}{*}{8} & \multirow{3}{*}{$\begin{array}{l}\text { Extension } \\
\text { participation }\end{array}$} & Low & 54 & 67.50 & 55 & 68.75 \\
\hline & & Medium & 10 & 12.50 & 10 & 12.50 \\
\hline & & High & 16 & 20.00 & 15 & 18.75 \\
\hline \multirow[t]{3}{*}{9} & \multirow[t]{3}{*}{ Cosmopoliteness } & Low & 29 & 36.25 & 28 & 35.00 \\
\hline & & Medium & 08 & 10.00 & 07 & 08.75 \\
\hline & & High & 43 & 53.75 & 45 & 56.25 \\
\hline \multirow[t]{3}{*}{10} & \multirow{3}{*}{$\begin{array}{l}\text { Achievement } \\
\text { motivation }\end{array}$} & Low & 26 & 32.50 & 24 & 30.00 \\
\hline & & Medium & 07 & 08.75 & 08 & 10.00 \\
\hline & & High & 47 & 58.75 & 48 & 60.00 \\
\hline
\end{tabular}


Table.2 Problems of tribal youth in securing their livelihood

\begin{tabular}{|c|c|c|c|c|c|c|c|}
\hline \multirow[t]{3}{*}{ Sl. No. } & \multirow[t]{3}{*}{ Problems* } & \multicolumn{6}{|c|}{ Tribal youth } \\
\hline & & \multicolumn{3}{|c|}{ Soliga $\left(n_{1}=80\right)$} & \multicolumn{3}{|c|}{ Kuruba $\left(n_{2}=80\right)$} \\
\hline & & No. & $\%$ & Rank & No. & $\%$ & Rank \\
\hline 1 & Inadequate land for cultivation & 79 & 98.75 & I & 78 & 97.50 & I \\
\hline 2 & Uncertainty of rainfall & 76 & 95.00 & III & 73 & 91.25 & III \\
\hline 3 & $\begin{array}{l}\text { Lack of knowledge about improved agricultural } \\
\text { technologies }\end{array}$ & 77 & 96.25 & II & 71 & 88.75 & V \\
\hline 4 & Inadequate fodder for cattle & 72 & 90.00 & $\mathrm{~V}$ & 75 & 93.75 & II \\
\hline 5 & $\begin{array}{l}\text { Inadequate irrigation facilities for farming and to } \\
\text { maintain live stock }\end{array}$ & 73 & 91.25 & IV & 72 & 90.00 & IV \\
\hline 6 & High price fluctuation for farm produce & 67 & 83.75 & VIII & 70 & 87.50 & VI \\
\hline 7 & $\begin{array}{l}\text { Lack of market intelligence and improper control } \\
\text { over traders in the regulated markets }\end{array}$ & 69 & 86.25 & VI & 67 & 83.75 & VII \\
\hline 8 & $\begin{array}{l}\text { Lack of awareness on government encouragement } \\
\text { about the subsidiary enterprises }\end{array}$ & 68 & 85.00 & VII & 60 & 75.00 & $\mathrm{X}$ \\
\hline 9 & Alternative irrigation & 65 & 81.25 & IX & 61 & 76.25 & IX \\
\hline 10 & $\begin{array}{l}\text { Lack of credit to invest on agriculture and allied } \\
\text { activities }\end{array}$ & 63 & 78.75 & $\mathrm{XI}$ & 59 & 73.75 & $\mathrm{XI}$ \\
\hline 11 & Wild animal threats & 64 & 80.00 & $\mathrm{X}$ & 57 & 71.25 & XII \\
\hline 12 & Lack of soil fertility & 56 & 70.00 & XII & 62 & 77.50 & VIII \\
\hline 13 & Lack of support from line department & 54 & 67.50 & XIV & 51 & 63.75 & XIV \\
\hline 14 & High cost of inputs & 55 & 68.75 & XIII & 47 & 58.75 & XVI \\
\hline 15 & Markets are far away & 47 & 58.75 & XV & 53 & 66.25 & XIII \\
\hline 16 & Lack of remunerative prices for the farm produce & 44 & 55.00 & XVI & 48 & 60.00 & $\mathrm{XV}$ \\
\hline 17 & Lack of veterinary facilities at the village & 38 & 47.50 & XVII & 41 & 51.25 & XVII \\
\hline 18 & Non availability of quality inputs & 27 & 33.75 & XVIII & 23 & 28.75 & XIX \\
\hline 19 & Distant location of land & 19 & 23.75 & XIX & 24 & 30.00 & XVIII \\
\hline 20 & Non availability of labour and high labour cost & 12 & 15.00 & $\mathrm{XX}$ & 19 & 23.75 & $\mathrm{XX}$ \\
\hline
\end{tabular}

*Multiple response 
Table.3 Suggestions of tribal youth for improvement of their livelihood status

\begin{tabular}{|c|c|c|c|c|c|c|c|}
\hline \multirow{3}{*}{$\begin{array}{l}\text { Sl. } \\
\text { No }\end{array}$} & \multirow[t]{3}{*}{ Suggestions* } & \multicolumn{6}{|c|}{ Tribal youth } \\
\hline & & \multicolumn{3}{|c|}{ Soliga $\left(n_{1}=80\right)$} & \multicolumn{3}{|c|}{$\operatorname{Kuruba}\left(\mathbf{n}_{2}=80\right)$} \\
\hline & & No. & $\%$ & Rank & No. & $\%$ & Rank \\
\hline 1 & $\begin{array}{l}\text { Need of 'Record of Right Tenancy and } \\
\text { Crops (RTC)' in the name of tribal youth }\end{array}$ & 80 & 100.00 & I & 80 & 100.00 & I \\
\hline 2 & Establishment of small scale enterprises & 72 & 90.00 & II & 79 & 98.75 & II \\
\hline 3 & $\begin{array}{l}\text { Organizing the training programmes at } \\
\text { village level on improved farm } \\
\text { technologies }\end{array}$ & 71 & 88.75 & III & 77 & 96.25 & III \\
\hline 4 & $\begin{array}{l}\text { Increase the support price for agriculture } \\
\text { produce }\end{array}$ & 70 & 87.50 & IV & 69 & 86.25 & IV \\
\hline 5 & $\begin{array}{l}\text { Conducting awareness programmes at } \\
\text { village level about the government } \\
\text { schemes }\end{array}$ & 69 & 86.25 & V & 66 & 82.50 & $\mathrm{~V}$ \\
\hline 6 & Providing subsidies for inputs & 51 & 63.75 & VI & 62 & 77.50 & VI \\
\hline 7 & $\begin{array}{l}\text { Veterinary facilities should be provided in } \\
\text { the village }\end{array}$ & 49 & 61.25 & VII & 53 & 66.25 & VII \\
\hline 8 & $\begin{array}{l}\text { Placement of field level officers at village } \\
\text { level }\end{array}$ & 44 & 55.00 & VIII & 51 & 63.75 & VIII \\
\hline 9 & $\begin{array}{l}\text { Permission should be provided for Non } \\
\text { timber forest products collection }\end{array}$ & 42 & 52.50 & IX & 49 & 61.25 & IX \\
\hline
\end{tabular}

*Multiple response 


\section{Problems of tribal youths in securing their livelihood status}

The problems of Soliga and Kuruban tribal youths in securing their livelihood status are presented in Table 2.

Inadequate land for cultivation (Rank I), lack of knowledge about improved agricultural technologies (Rank II), uncertainty of rainfall (Rank III), inadequate irrigation facilities for farming and to maintain live stock (Rank IV), Inadequate fodder for cattle (Rank V), lack of market intelligence and improper control over traders in the regulated markets (Rank VI), lack of awareness on government encouragement about the subsidiary enterprises (Rank VII), high price fluctuation for farm produce (Rank VIII), alternative irrigation (Rank IX) and wild animal threats (Rank X) were the major ten problems of Soliga youths in securing their livelihood status.

The important ten problems of Kuruba tribal youths in securing livelihood status are: inadequate land for cultivation (Rank I), inadequate fodder for cattle (Rank II), uncertainty of rainfall (Rank III), inadequate irrigation facilities for farming and to maintain live stock (Rank IV), lack of knowledge about improved agricultural technologies (Rank V), high price fluctuation for farm produce (Rank VI), lack of market intelligence and improper control over traders in the regulated markets (Rank V), high price fluctuation for farm produce (Rank VI), lack of market intelligence and improper control over traders in the regulated markets (Rank VII), lack of soil fertility (Rank VIII), alternative irrigation (Rank IX) and lack of awareness on government encouragement about the subsidiary enterprises (Rank X). The results of the present study are supported by finding of Marbaniang et al., (2013) and Patel et al., (2015).
The Central and State Governments should address the above problems of Soliga and Kuruba tribal youths for improvement of their livelihood status.

\section{Suggestions of tribal youth for improvement of their livelihood status}

The suggestions of Soliga and Kuruba youths for improving their livelihood status are presented in Table 3.

Need of 'Record of Right Tenancy and Crops (RTC)' in the name of tribal youth (Rank I), establishment of small scale enterprises (Rank II), organizing the training programmes at village level on improved farm technologies(Rank III), increase the support price for agriculture produce (Rank IV), conducting awareness programmes at village level about the government schemes (Rank V), providing subsidies for inputs (Rank VI), veterinary facilities should be provided in the village (Rank VII), placement of field level officers at village level (Rank VIII) and permission should be provided for Nontimber forest products collection (Rank IX) are the suggestions of both Soliga and Kuruba tribal youths for securing their livelihood status. The findings of Mamathalakshmi (2013) and Dhanasree et al., (2014) mirrored the present study findings.

The above suggestions should be implemented by the concerned authorities for improving the livelihood status of Soliga and Kurubatribal youths.

It can be concluded from the results of the study that there exists difference in the personal, socio-economic, psychological and communication characteristics between of Soliga and Kuruba tribal youths.

Majority of the tribal youth faced the problems of inadequate land for cultivation, 
uncertainty of rainfall and lack of knowledge about improved agricultural technologies. Therefore, action has to be initiated by the Government to provide; (a) more land in the name of tribal youth, (b) assured irrigation facilities, and(c) agriculture extension services should be extended to the tribal youth. In addition to these, there is a need for providing financial support by the Government to the tribal youths for taking up income generating activities for securing livelihood status. RTC of land should be provided in the names of tribal youth to get more benefits from government and other organisations.

\section{References}

Dhanasree, K., Vijayabhinandana, B. and Pradeepkumar, P. B., 2014, Socioeconomic empowerment of tribal women in high altitude and tribal zone of Andhra Pradesh. Int. J. Inno. Res. Sci., Engg. Tech., 3(2): 9360-9368
Mamathalakshmi, N., 2013, An analysis of livelihood security among agricultural labourers in Karnataka, Ph.D, (Agri) Thesis (Unpub.), Univ. Agric. Sci., Bangalore

Marbaniang, E. K., Manjunath, L., Angadi, J. G., and Banakar, B., 2013, Demographic characteristics of Tibetan rehabilitants and their livelihood activities. Karnataka J. Agric. Sci., 26 (2): 247-250

Patel, V.M., Mistry, J.J., and Sutariya, B.A., 2015, Attitude of tribal farmers towards well recharging. Gujarat J. Extn.Edn., 26(1): 74-76.

Rokonuzzaman, M., 2013, Training needs of tribal people regarding income generating activities. Indian Res. J. Extn.Edn., 13(2): 10-16

Yashodhara, B., 2015, A comparative analysis of livelihood status in irrigated and rainfed farming situations in central dry zone of Karnataka. Ph.D Thesis (Unpub.), Univ. Agric. Sci., Bangalore.

\section{How to cite this article:}

Bharath Kumar, T.P., M.S. Nataraju and Lakshminarayan, M.T. 2019. A Comparative Analysis on Profile and Problems of Soliga and Kuruba Tribal Youths. Int.J.Curr.Microbiol.App.Sci. 8(10): 2529-2536. doi: https://doi.org/10.20546/ijcmas.2019.810.293 